these communities never had the true grounds for an independent existence, and after all, that was why they were in the federation.

In other words, the exclusive claims of "superior" nationalisms steal the historicity of communities who are imprisoned in the nomenclature of ethnic minorities. In this context, the ultimate truth to the tragedy of the Yugoslavian civil war is that it has a generic nature which echoes the main premises of the "one nation to one nation-state" model of the European tradition, and as such, it is prone to perpetual reproduction. 1 .

\section{Notes}

1. See Kuper, Leo, "The Prevention of Genocide: Cultural and Structural Indicators of Genocidal Threat," Ethnicand Racial Studies, Vol. 12 No. 2 (April 1989).

2. See Knight, D. B., "Identity and Territory: Geographical perspectives on Nationalism and Regionalism," Annals of Association of American Geographers 72 (1982), and, Brunn, S., "The Future of the Nation-State System," in P. J. Taylor, and J. House, eds., Political Geography. Recent Advances and Future Directions, London: Croom Helm (1984).

3. See Lendvai, Paul, "Yugoslavia Without Yugoslavs: The Roots of the Crisis," International Affairs, Vol. 67 No. 2(1991), and Anton Bebler, "Yugoslavia's Society of Communist Federalism and Her Demise," Communist and Post-Communist Studies, Vol. 26 (March 1993).

4. Denitch, Bogdan. "Tragedy in Former Yugoslavia," Dissent, Vol. 26 (Winter 1993).

5. Lendvai, 1991, p. 253.

6. See Giddens, Anthony, The Nation-State and Violence, Cambridge: Polity Pres (1985), and Aristide, Zolberg, A. Suhrke, and S. Aguayo, eds., Escape from Violence: Conflict and the Refugee Crisis in the Developing World, New York: Oxford University Press (1989).

7. See Ben-Dor, Gabriel, "Political Culture Approach to Middle East Politics," International Joumal of Middle East Studies 8, 1 (1977).

8. As one of the most prominent thinkers of a constructive critique of social geography, Lefebvre re-articulates Giddens's critique of the central state apparatus in his writings on the cultural formations of everyday life in pre-modern Europe. There, the time and space dimensions are interlinked in such a way that power and locality are analysed as the two components of a single unit: the sociopolitical organisation of an operative community. In my work, I would like to elaborate on Lefebvre's notion of "locale' in the specific context of ethno-nationalist/ proto-nationalist ideologies. $\square$

\title{
Crisis in Bosnia-Herzegovina and the Myth of Preventive Protection
}

\author{
Michael Barutciski
}

The concept of "preventive protection" (or preventive diplomacy) has been used by UNHCR in recent years to help justify its shift of focus from external asylum to internal assistance. In the case of the former Yugoslav Republic of Bosnia-Herzegovina, it is inappropriate for the powerful states that control $U N H C R^{1}$ to speak of preventive protection when their foreign policy had more to do with geopolitical objectives than with finding a solution that could have realistically helped avert the war. This article presents selected legal problems that help in understanding the armed conflict in Bosnia-Herzegovina.

\section{Three Nations}

There were three constituent nations in the former Yugoslav Republic of Bosnia-Herzegovina: Croats, Serbs and Muslims. According to the 1981 census figures, the population of the Republic was composed as follows: 20 percent Croat, 37 percent Serb, 40 percent Muslim. The remainder of the population included various minorities and people who identified themselves as "Yugoslavs." 2 The term from which the translation "nation" is obtained, narod, is used in the 1974 Constitution in a way that most resembles the German Volk in that it refers to a people defined culturally rather than to citizenry.

There has been a certain confusion in the way many western media sources have used the terms "Muslim" / "Bosnian." Muslims were recognized de facto as a distinct nation in the 1971 census and de jure in the 1974 Consitution. ${ }^{3}$ With their own growing nationalist sentiment, Muslims resented being referred to as "Serbs" or

Michael Barutciski is a Atle Grahl-Madsen Fellow in Law at CRS, York University.
"Croats" who had simply converted to Islam under the Ottoman rule in order to enjoy privileges. Likewise, the term "Yugoslav" did not accommodate their desire to have their own distinct culture recognized. Therefore, the term "Muslim" (with a capital " $M$ ") was officially adopted.

Focusing on the legal terms regarding the various nations in BosniaHerzegovina helps avoid confusion and manipulation. Since the term "Bosnian" does not distinguish which of the three nations is being referred to, its use can easily lead to confusion. For example, using the term to designate the Muslims (as is often done in the western media) leads to the erroneous identification of the state (reduced by the media to "Bosnia") with the Muslim population. This ignores the fact that the majority of the inhabitants of Bosnia-Herzegovina belong to the Croat and Serb nations and have been present on the territory for as long as the Muslims themselves. Using the term "Bosnian" as a multi-ethnic category which includes all three nations is also misleading since it does not accurately reflect the political forces at play:

Let's not kid ourselves either about the nature of the [Muslim-controlled] Bosnian government... It is only to the outside world that the Bosnian government maintains the fiction of its "multi-ethnic" character, for the obvious reason that a multi-ethnic state is more likely to get international aid. ${ }^{4}$

These comments lead us to other legal issues regarding the representation of the inhabitants of Bosnia-Herzegovina.

\section{Constitutional Crisis}

Even though it is the source of the present armed conflict, there has been almost no discussion of the constitu- 
tional crisis in Bosnia-Herzegovina. The first free elections of that state's short history (Tito's Communists created the Republic by joining two geographic regions at the end of World War II) were held in 1990 and resulted in the nationalist parties of the three constitwent nations taking 86 percent of the wote in proportions generally reflecting their percentages of the population. 5

The three nationalist parties agreed to share various functions at the Republican level. ${ }^{6} \mathrm{This}$ was in accordance with the 1974 Constitution which provided for the equality of the three constituent nations. At the local level, however, absolute control was seized by the party that represented the majority group in each particular region. ${ }^{7}$ The tensions in the parliament of Bosnia-Herzegovina finally exploded when the Muslim and Croat parties agreed to proclaim the sovereignty of Bosnia-Herzegovina in October, 1991. The Serbs withdrew and created their own parliament near Sarajevo (Pale). ${ }^{8}$

In the meantime, the parliament of Bosnia-Herzegovina found itself at an impasse since it had to enact a new constitution in order for the state to become independent. To do this legally, it needed the participation of the Serb parliamentarians.

\section{Recognition of Independence}

Despite the fact that the parliament of Bosnia-Herzegovina no longer contained the elected representatives of one of the constituent nations and that the state was as constitutionally illegitimate as the state of Yugoslavia following the withdrawal of Slovenia and Croatia, the Muslim-controlled Presidency decided to seek international recognition for the independence of Bosnia-Herzegovina. The European Community's Arbitration Commission (composed of the presidents of five European Union (EU) member constitutional courts and assigned to deal with legal problems regarding the former Yugoslavia) was thus notified on December 20,1991, so that it could examine the request. The very suggestion that the EU made it possible for
Bosnia-Herzegovina to ask that its independence be recognized under those circumstances left those who were aware of the situation very worried. 9

Nonetheless, the request was examined and an advisory opinion was given on January $11,1992 .{ }^{10}$ The Arbitration Commission rejected the request while noting "that the Serbian members of the Presidency did not associate themselves" with the various independence declarations and undertakings. Referring to the wishes of the Serbs to remain in a Yugoslav federation as established by a plebiscite and a Serb Assembly resolution, the Arbitration Commission declared "that the

... When the predictable
refugee flows began crossing
borders, these same states
[with self-interest] avoided
providing refuge for victims
of the war...

will of the peoples of Bosnia-Herzegovina to constitute the SRBH [Socialist Republic of Bosnia-Herzegovina] as a sovereign and independent State cannot be held to have been fully established." It concluded that its position could be reviewed if "appropriate guarantees were provided by the Republic applying for recognition, possibly by means of a referendum of all the citizens of the SRBH without distinction, carried out under international supervision" (emphasis added).

The Muslim and Croat parliamentarians thus decided to hold a referendum on independence even though the Serbs vowed to boycott it. The results were made public on March 1 , 1992: the Muslims and Croats who participated voted overwhelmingly for independence, while the Serbs effectively boycotted the referendum.

Yet the EU's policy on BosniaHerzegovina was more nuanced. Along with the possibility of recognition, the EU organized negotiations between the three sides so that the Republic could become a confederation divided into three ethnic regions. It had been clear for many months that no agreement between the three nationalist parties could be achieved legally and legitimately that did not involve a substantial transfer of power from the centralized Republican government to the representatives of the three constituent nations.

Moreover, none of the parties would accept any form of domination by another party. The Muslims and the Croats feared the Serb nationalist party which was under the influence of Serbia's aggressive President Milosevic; the Muslims and the Serbs also feared the Croat nationalist party which included hard-liners associated with the nationalist party of Croatia's President Tudjman; the Serbs and the Croats equally feared the Muslim nationalist party which included some radical Islamic tendencies. ${ }^{11}$ So it is not surprising that negotiations were held between the three constituent nations in order to divide the territory of Bosnia-Herzegovina in a manner that would be acceptable to the nationalist leaders. Indeed, such an agreement was finally reached on February 23, 1992, in Lisbon.

\section{International Intervention}

Yet it would be a grave mistake to believe that the actors at this stage were only former Yugoslavs. The emerging conflict had captured the attention of various interests around the world and this resulted in certain powerful states reacting accordingly. ${ }^{12}$ Of particular importance is the United States intervention: the US Ambassador to Yugoslavia at the time has since admitted in an interview that he convinced President Izetbegovic to publicly renounce the Lisbon agreement soon after having signed it. ${ }^{13}$ This was done because the US government had decided at that point to recognize the Republic and to support Izetbegovic's government in the UN if it "got into trouble." Consequently, the US government convinced the EU states to recognize the Republic on April 6, 1992 by agreeing to recognize Croatia and Slovenia along with Bosnia-Herzegovina the following day. ${ }^{14}$ 
Thus the international community proceeded to recognize the independence of a state that had ceased to exist in any meaningful way: the constitutional crisis had left a parliament that no longer represented the three constituent nations, the Muslim-controlled Presidency's authority was denied by a majority of its putative citizens and the territory was being seized by violent militia units from the various constituent nations. As the government was being taken over by the Muslims, it was given a seat in the UN's General Assembly despite the fact that it was engaged in an armed conflict with the other two constituent nations. In the context of the brutal disintegration of the former Yugoslavia, this situation only helped to assure that the parties to the conflict in BosniaHerzegovina would seek their goals ${ }^{15}$ by the most ruthless military means.

Far from preventing an explosive situation, self-interested members of the international community contributed in aggravating a situation that any informed observer should have known would lead to massive displacement of civilian populations:

By denying that partition of Bosnia could take place when in fact it was inevitable, the international community ensured that it would be accomplished in the worst possible way. The map of Bosnia was redrawn in blood on the ground, rather than around a table. ${ }^{16}$

Furthermore, when the predictable refugee flows began crossing borders, these same states avoided providing refuge for victims of the war while insisting that their contribution to refugee protection would focus on concepts such as "preventive protection." The case of Bosnia-Herzegovina is an example of these concepts being used essentially to help powerful states justify to their own populations the containment of refugee flows.w

\section{Notes}

1. Contrary to the fixed budgets that are guaranteed to many UN agencies, UNHCR is almost entirely funded by voluntary contributions. The top con- tributor for 1992 was the United States (240 690000 \$US) followed by the European Community (228 870000 \$US). See UNHCR, The State of the World's Refugees, New York: Penguin Books, 1993, p. 177.

2. See, for example, Denitch B., Ethnic Nationalism: The Tragic Death of Yugoslavia, Minneapolis: University of Minnesota Press, 1994, p. 206. These figures are generally more reliable than the 1991 census figures.

3. The Communist Party actually began recognizing a distinct Muslim nation in the late 1960s "Un plénum du Comité Central du Parti Communiste de Bosnie a officiellement proclamé le 17 mai 1968 que les 'Musulmans comme le démontre notre praxis socialiste sont une nation àpart'." Le Monde, March 29, 1969, p. 111. See A. Popovic, Les Musulmans yougoslaves, Lausanne: L'Age d'Homme, 1990, p. 25, 36.

4. Kenney, G. (former State Department desk officer on Yugoslavia who quit in protest over U.S. policy). “A Forced Peace Is Worth Trying", L.A. Times, 6 February 1994.

5. SDA (Muslim): 86 parliamentary seats; SDS (Serb): 72; HDZ (Croat): 44; Communists (multi-ethnic): 20; Markovic's Reformist Party (multi-ethnic): 13. See P. Garde, Vie et mort de la Yougoslavie, Paris: Fayard, 1992, p. 292

6. The leader of the Muslim nationalist party, Alija Izetbegovic, became the President of the Republic's Presidency, while Momcilo Krajisnik (Serb) became the parliamentary President and Jure Pelivan (Croat) became the Prime Minister. For a discussion of the constitutional developments, see S. Bogosavlevic et al., Bosna $i$ Herzegovina izmedju rata i mira, Belgrade and Sarajevo: Forum za etnicke odnose, 1992.

7. Hayden, R. "Constitutional Nationalism in the Formerly Yugoslav Republics," (1992) 51 Slavic Review 654, at 661.

8. Ibid. Several months later the Croats had also created their own state in western Herzegovina. See $H$. Wynaendts, L'engrenage - Chroniques yougoslaves, Paris: Denoell, 1993, p. 153. Yet in the meantime, there was an objective need for the Croats to be allied with the Muslims in order to separate from Yugoslavia, which at that point was clearly Serb-controlled. This however did not prevent the Croats from organizing their own military units which were not under the command of the Muslim President.

9. As a senior European diplomat who served as the assistant to the Chairperson of the EU's Peace Conference on Yugosla- via has stated: "La décision de demander a la Bosnie-Herzegovina si elle voulait étre indépendante était, selon Carrington, 'une erreur tragique'". Wynaendts, H.,id., p. 154.

10. Conference on Yugoslavia Arbitration Commission Opinion No 4, in (1992) 31 International Legal Materials 1501.

11. Unlike Serb and Croat nationalism, the rising Muslim nationalism of the last few decades has hardly been mentioned by the western media. The Muslim nationalist party is actually quite divided, including "atheist" Muslims and "politically Islamicized" Muslims. This has left western journalists confused over certain violent events between Muslims: J. Burns, "New Horror for Sarajevo: Muslims Killing Muslims," The New York Times, October 31, 1993, p. 10. For an example of the Muslim nationalist party's religious component, see President Izetbegovic's Islamska Deklaracija, (Sarajevo: Mala Muslimanska Biblioteka, 1990). This is a fundamentalist text written in 1970 that was published and widely distributed during the 1990 elections and includes the following phrases: "Our goal: Islamization of Muslims... There can be no peace or coexistence between Islamic faith and non-Islamic institutions... The Islamic movement must and can take power as soon as it is morally and numerically strong enough, not only to destroy the non-Islamic power, but to build up a new Islamic one" (author's own translation).

12. For a discussion of the particular American interests in the region, see P.-M. de la Gorce, "Les risques d'extension du conflit en Bosnie", Le Monde diplomatique, January, 1993, p. 9, and "La crise yougoslave prise en main par Washington", Le Monde diplomatique, April 1994, p. 11.

13. Binder, D. "U.S. Policymakers on Bosnia Admit Errors in Opposing Partition in 1992," The New York Times, August 29, 1993, p. 10.

14. Ibid. See also Palmer, M., "US Forces Early Move on Bosnia", Guardian, March10, 1992, p. 8.

15. "Il devient clair que la fuite et le déplacement de la population ne sont pas uniquement la conséquence de la guerre mais également un de ses objectifs: aboutir a des territoires 'ethniquement purs'." M. Morokvasic, "La guerre et les réfugiés dans l'ex-Yougoslavie," (1992) 8 Revue européenne des migrations internationales 5, at 9.

16. Hayden, R. "U.S. Efforts to Resolve Balkan Crisis Have Only Added to Muslim's Losses," Sun-Sentinel, February 9, 1994, p. 19. व 